with an Arctic flora on the Cumbrian coast, where Dr. Bernard Smith has detected a peat with a temperate flora between two glacial deposits, and on the Durham coast, where Dr. Trechmann has found an accumulation claimed as loess similarly intercalated. Then there is the significant section at Kirmington. By the way, if the Kirmington tract was submerged, why not that of March also, lying further south?

I may note that anyone examining the glacial deposits of the Cambridgeshire plateau might well argue for a single glaciation there, though Messrs. Rastall and Romanes considered that earlier glacial deposits here were ploughed up by, and their contents incorporated with, those of a later period. It is chiefly in the valleys where the gravels were deposited in considerable thickness, and afterwards protected from later ice, according to my view, that the evidence for their intercalation between two periods of glaciation of the district is obtainable.

Cambridge.

John E. Marr.

18 th March, 1926.

\title{
GEOLOGY OF THE EAST INDIES.
}

Sir,-May I invite the attention of English geologists interested in the East Indies to a book recently published by The Macmillan Company in the U.S.A., The Geology of the Netherlards East Indies, by Professor H. A. Brouwer, of Deft. The book is a series of lectures delivered at Michigan University, and is a most valuable summary in English of a mass of Dutch geological literature. On inquirin: for the book in England I found it was unknown, even by Macmillan and Company, Ltd., London. It was published in New York in October, 1925.

J. B. Scrivenor. 